\title{
Effect of Surface Hardness and Hydrogen Sulfide Partial Pressure on Sulfide Stress Cracking Behavior in Low Alloy Linepipe Steel
}

\author{
Junji Shimamura ${ }^{1 *}$, Daichi Izumi $^{1)}$, Itaru Samusawa ${ }^{1)}$ and Satoshi Igi $^{1)}$ \\ 1) Steel Research Laboratory, JFE Steel Corporation
}

Abstract: TMCP (thermo-mechanical controlled process) linepipes have been long used for severe sour environment, but recently sulfide stress cracking (SSC) caused by local hard zones has become a concern. In order to clarify the hardness threshold that leads to SSC, four-point bend (4PB) SSC tests as per NACE TM0316 were conducted under several $\mathrm{H}_{2} \mathrm{~S}$ partial pressure conditions. For 1 bar and higher $\mathrm{H}_{2} \mathrm{~S}$ partial pressure conditions, the surface hardness threshold (at $0.25 \mathrm{~mm}$ from surface) observing 4PB SSC specimens without SSC cracking was approximately correlated to a maximum acceptable hardness level of 250 HV0.1. By suppressing the hard lath bainite (LB) and obtaining the soft granular bainite (GB) microstructure, stable low surface hardness of 250 or less HV0.1 was achieved, resulting in superior SSC-resistant property. On the other hand, it was found that SSC crack propagated when the surface hardness increased with increasing the volume fraction of LB microstructure. In the case of $16 \mathrm{bar}_{2} \mathrm{~S}$ partial pressure condition, the crack growth rate increased in the sour environment, and hydrogen embrittlement by $\mathrm{H}_{2} \mathrm{~S}$ was promoted. However, in the $4 \mathrm{~PB}$ SSC test at 16 bar, since the shape of localized corrosion is semicircular due to low localized corrosivity, it was considered that the stress concentration and transition to crack were suppressed. This may be the reason why the SSC susceptibility was similar to 1 bar condition, especially in the 4PB SSC test using the samples with lower surface hardness level of 250 or less HV0.1.

Keywords: linepipe; low alloy steel; sulfide stress cracking; thermo-mechanical controlled process; bainite; hardness; SSC crack propagation; hydrogen embrittlement; active path corrosion.

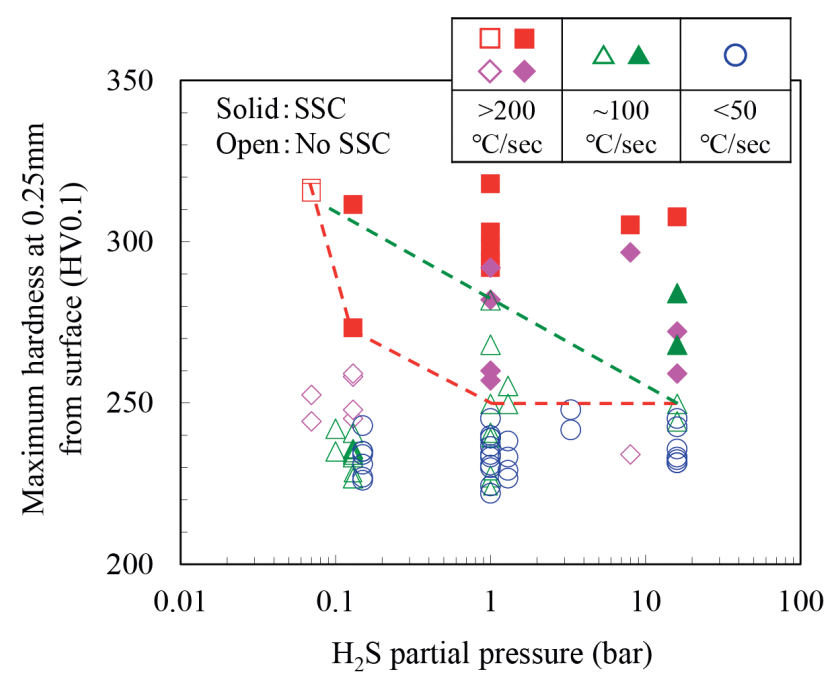

Received on Nov. 27, 2020 ; Accepted on Jan. 13, 2021 ; J-STAGE Advance published on Feb. 9, 2021

* Corresponding author. E-mail: j-shimamura@jfe-steel.co.jp, Address: JFE Steel Corporation, 1 Kokan-cho Fukuyama Hiroshima 721-8510 


\title{
低合金鋼ラインパイプの硫化物応力腐食割れ挙動に 及ぼす極表層硬さおよび硫化水素分圧の影響
}

\author{
嶋村 純二 ${ }^{1)} *$. 泉 大地 $^{1)} \cdot$ 寒沢 至 ${ }^{1)} \cdot$ 伊木 聡 ${ }^{1)}$ \\ Effect of Surface Hardness and Hydrogen Sulfide Partial Pressure on Sulfide Stress Cracking Behavior \\ in Low Alloy Linepipe Steel \\ Junji Shimamura, Daichi Izumi, Itaru Samusawa and Satoshi Igi
}

\section{1. 緒言}

海底の油田・ガス田の掘削において, 石油・天然ガス輸 送用パイプラインには厚板鋼板を素材として造管され製造 されるラインパイプ (UOE鋼管) が用いられる ${ }^{1)}$ 。ライン パイプに要求される特性としては, 強度, 勒性に加えて耐 腐食性が求められる ${ }^{2)}$ 。特に, 硫化水素 $\left(\mathrm{H}_{2} \mathrm{~S}\right)$ ガスや炭酸 $\left(\mathrm{CO}_{2}\right)$ ガス等腐食性ガスを含んだ湿潤サワー環境におい て, 水素誘起割れ (HIC) や硫化物応力腐食割れ (SSC) に 対して十分な耐性が必要となる ${ }^{3-5)}$ 。

SSC は, 古くは1940年代終わりにカナダのアルバータ で発生した ${ }^{6)}$ 。1980年代に制御圧延・制御冷却いわゆる TMCPプロセスで製造された厚板鋼板を用いたラインパイ プにおいて, SSCに対する対策がとられ，厚板 TMCP技術 が発展してきた ${ }^{5)}$ 。以後, 多くの研究が進められ, SSC は主 に材料 ${ }^{7-9)}$, サワー環境 ${ }^{10,11)}$, 負荷応力 ${ }^{12,13)}$ の3つの要因に よって影響を受けることが知られている。耐サワーライン パイプの設計では, SSCを回避するため, 材料にはNACE MR0175/ISO 15156-1規格に示されるような硬度制限が設 けられ, 炭素鋼や低合金鋼では $22 \mathrm{HRC}$ (約250 HV10) の硬 度上限が規定されている ${ }^{14)}$ 。また，一般的なラインパイプ の規格であるAPI Spec 5Lには, パイプ内外面の表面から $1.5 \mathrm{~mm}$ の位置が $250 \mathrm{HV} 10$ 以下であることが規定されてい る。これらの硬さ規定は多くの耐サワーラインパイプに適 用され, 従来の 1 bar以下の $\mathrm{H}_{2} \mathrm{~S}$ 環境の試験においては SSC に対する安全性が実証されてきた。しかし，1 barを超える 綮しい $\mathrm{H}_{2} \mathrm{~S}$ 環境における $\mathrm{SSC}$ 試験は，特に低合金鋼ライン パイプに対して，これまでほとんど行われておらず，材料 の適合性に不明な点が多い。

一方, 近年, 従来よりも厳しい 1 barを超える $\mathrm{H}_{2} \mathrm{~S}$ 環境に おいて, SSCが発生した。その原因の一つとして, TMCP で製造するラインパイプの極表層領域の硬化部形成に焦
点が当たり, 極表層硬さや $\mathrm{H}_{2} \mathrm{~S}$ 分圧が $\mathrm{SSC}$ にぼす影響に ついて, 新たな調査が必要となった ${ }^{15)}$ 。従来の硬さ測定位 置の表層 $1.5 \mathrm{~mm}$ の硬さHV10だけでは耐SSC性を評価で きず，さらに表層に近い $0.25 \mathrm{~mm} 0.5 \mathrm{~mm}$ 位置の微小硬 さHV0.5あるいはHV0.1で整理することが提案されてい る ${ }^{16,17)}$ 。断面ビッカース硬さ測定の荷重が小さくなるほど 圧痕サイズが小さくなるため, 極表層に近い微視的領域の 硬さ判定が可能となる。従来, このような極表層に近い局 所硬化部が表面腐食挙動や SSC き裂発生・伝播に及ぼす影 響については必ずしも明確でなかった。

SSC 機構については, 水素脆性 (Hydrogen Embrittlement： HE）支配型 ${ }^{18)}$, あるいはHEと活性経路腐食 (Active Path Corrosion：APC）の複合型 ${ }^{19)}$ と考えられているが, SSCを 発生と伝播に切り分けた場合, その詳細機構については十 分な理解が得られていない。特に, 湿潤サワー環境におけ る $\mathrm{H}_{2} \mathrm{~S}$ 分圧の条件によって, HEと APCの寄与が変化する ものと推定されるが, $\mathrm{H}_{2} \mathrm{~S}$ 分圧条件が SSC 機構に及ぼす影 響については不明な点が多く, 初期の腐食挙動およびSSC 発生・伝播の過程をそれぞれ切り分け, 考察する必要があ ると考えられる。

本研究では, はじめに, 低合金ラインパイプの内表面の 極表層硬さ分布 (特にパイプ内表層 $0.25 \mathrm{~mm}$ 位置の微小硬 さHV0.1）や $\mathrm{H}_{2} \mathrm{~S}$ 分圧条件が耐 SSC 性に及ぼす影響につい て示す。その後, X65 級の $\mathrm{GB}$ 主体組織を前提とし, $\mathrm{H}_{2} \mathrm{~S}$ 分 圧条件が而 SSC 性に及ぼす影響について, SSC機構も含め て明らかにすることを目的とした。具体的には, 4PB SSC 試験により, サワー環境での腐食挙動および腐食生成物性 状に対する $\mathrm{H}_{2} \mathrm{~S}$ 分圧の影響を確かめるとともに, 電気化学 測定 (分極測定) により上記結果を検証した。さらに, サ ワー環境中でのノッチ付き SSRT 試験や歪漸増型破壊試験 により $\mathrm{H}_{2} \mathrm{~S}$ 分圧が俺裂伝播特性に及ぼす影響を評価した。

2020年11月27日受付２021年1月13日受理２021年2月9日Ｊ-STAGE早期公開（Received on Nov. 27, 2020；Accepted on Jan. 13, 2021；J-STAGE Advance published on Feb. 9, 2021)

1）JFEスチール (株) スチール研究所 (Steel Research Laboratory, JFE Steel Corporation)

* Corresponding author. E-mail : j-shimamura@jfe-steel.co.jp, Address: JFE Steel Corporation, 1 Kokan-cho Fukuyama Hiroshima $721-8510$

(c) (i) $(-) 2021$ The Iron and Steel Institute of Japan. This is an open access article under the terms of the Creative Commons Attribution-NonCommercialNoDerivatives license (https://creativecommons.org/licenses/by-nc-nd/4.0/deed.ja). 


\section{2. 実験方法}

\section{$2 \cdot 1$ 供試材}

供試材には管厚 20 〜 $30 \mathrm{~mm}$ の X65 級ラインパイプを用 いた。厚板鋼板製造時の TMCP 条件における表層冷却速 度の異なるパイプから $300 \mathrm{~mm}$ 角のクーポンを切り出し, $250^{\circ} \mathrm{C}$ で 1 時間のコーティング模擬した時効処理を施した。 Fig.1 に代表的なパイプ内表面のミクロ組織を示す。X65 級ラインパイプでは，通常，表層ミクロ組織はべイナイト 組織を形成する。べイナイト組織は，一般的にはラス状に

(a) $>200^{\circ} \mathrm{C} / \mathrm{sec}$

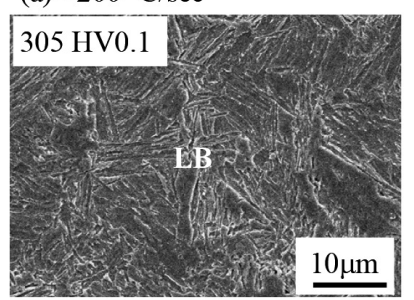

(c) $<50^{\circ} \mathrm{C} / \mathrm{sec}$

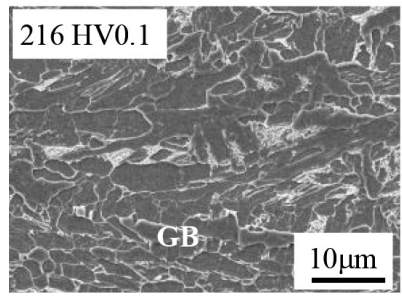

Fig. 1. Effect of surface cooling rate on surface microstructure.
形成したベイニティックフェライト（Bainitic Ferrite：BF） を基相とし， BF 界面に炭化物が析出するか，もしくは析 出のないものを上部べイナイト (Upper bainite), BF 粒内 に炭化物が析出するものを下部べイナイト（Lower bainite） と分類する場合が多い ${ }^{20)}$ 。しかし，ラインパイプ用鋼の ような低炭素鋼に打いては，冷却速度が遅い場合にBF が 粒状（Granular）に成長することから，ここではBF の形 態によってラスベイナイト (Lath bainite : LB) とグラニュ ラーベイナイト（Granular bainite：GB）に分類する。表 層冷却速度が $200^{\circ} \mathrm{C} / \mathrm{sec}$ を超える高い冷却速度では硬質の $\mathrm{LB}$ 主体組織となり，50 $\mathrm{C} / \mathrm{sec}$ を下回る低い冷却速度では 軟質なグラニュラーベイナイト GB 主体組織となる。中間 の約 $100^{\circ} \mathrm{C} / \mathrm{sec}$ の冷却速度では LB と GBの混合組織となる。 Fig.2 にパイプ内表面の硬さ分布例を示す。 $100^{\circ} \mathrm{C} / \mathrm{sec}$ 以上 の高い冷却速度の鋼板を用いたパイプは，板厚方向と幅方 向ともに広い領域で高硬度を示す傾向がみられた。一方， 冷却速度が $50^{\circ} \mathrm{C} / \mathrm{sec}$ 以下の場合，板厚方向と幅方向とも に広い領域で低硬度を示した。特にこの低い冷却速度では 表層 $0.25 \mathrm{~mm}$ 位置に打いて硬さが安定的に 250 HV0.1 を下 回っている。これらの時効後パイプの内表層から $5 \mathrm{~mm}$ 厚 の試験片を採取し，4 点曲げ SSC 試験を実施した。

Fig.3にパイプ内表面から管厚方向へ測定した硬さ分布 例を示す。表層冷却速度に拠らず，パイプ内表層 $1.0 \mathrm{~mm}$ 超える管内部ではHV0.1の硬さは低下し，ほぼ同等レベル の硬さとなっており，GB主体の組織であった。後述する

(b) $\sim 100{ }^{\circ} \mathrm{C} / \mathrm{sec}$

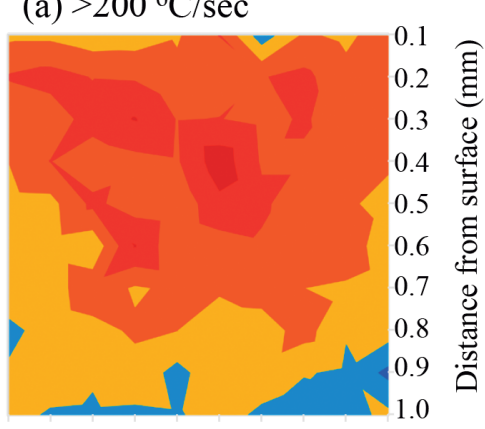

$\begin{array}{llllllllll}10 & 9 & 8 & 7 & 6 & 5 & 4 & 3 & 2 & 1\end{array}$

Distance in width direction $(\mathrm{mm})$
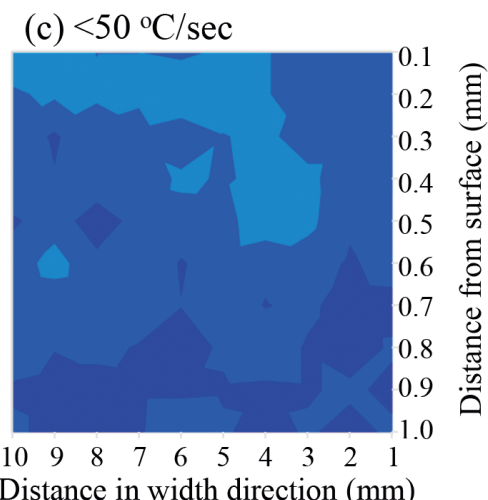

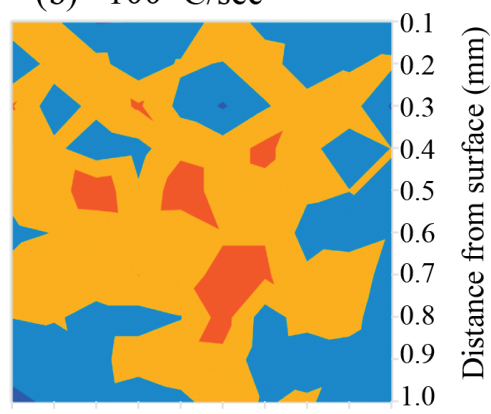

$\begin{array}{llllllllll}10 & 9 & 8 & 7 & 6 & 5 & 4 & 3 & 2 & 1\end{array}$

Distance in width direction $(\mathrm{mm})$

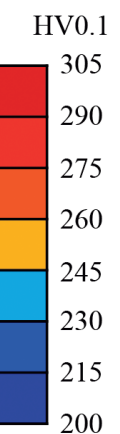

Fig. 2. Effect of surface cooling rate on surface hardness distribution. 
丸棒引張試験片やノッチ付き丸棒引張試験片, CT 試験片 はこの硬さ定常位置より採取し，各試験に供した。

\section{$2 \cdot 24$ 点曲げSSC 試験方法}

耐SSC 性能を評価するため, NACE TM0316規格 ${ }^{21)}$ に準 拠し，様々な $\mathrm{H}_{2} \mathrm{~S}$ 分圧条件下で 4 点曲げ SSC 試験を実施し た。パイプ内表層から $5 \mathrm{~mm}$ 厚の 4 点曲げ試験片を表面黒 皮ままで採取した。SSC試験条件をTable1に示す。また, Fig.4のサワー環境のシビアリティマップに今回の SSC試 験条件を合せて示す。NACE TM0177 A 溶液 ${ }^{22)}$ を使用した 試験では, $\mathrm{H}_{2} \mathrm{~S}$ 分圧は 1 16 barの範囲とした。 $\mathrm{H}_{2} \mathrm{~S}$ 分圧が 8 bar 扎よび 16 barの条件では, 5 barの $\mathrm{CO}_{2}$ との混合ガスを使 用した。NACE TM0177 B 溶液 ${ }^{22)}$ を使用した試験では, $\mathrm{H}_{2} \mathrm{~S}$ 分圧は $0.07 〜 0.13$ barの範囲とし, $\mathrm{CO}_{2}$ を混合して総ガス 圧は 1 barとした。NACE TM0177 Buffered溶液を使用した 試験では, $\mathrm{H}_{2} \mathrm{~S}$ 分圧 $0.15 \mathrm{bar}, \mathrm{CO}_{2}$ 分圧 $0.85 \mathrm{bar}$, 試験開始時 pH3.1を狙いとした。Fig.5に4点曲げSSC 試験の治具の模 式図を示す。パイプ内表面側を 4 点曲げの引張側にセット し，時効前パイプの $90 \% A Y S$ (Actual Yield Strength) (460〜 $486 \mathrm{MPa})$ の応力を負荷した。試験時間は 720 時間とし, 試 験終了後の試験片の中央部を切断, 研磨し, 割れの有無を

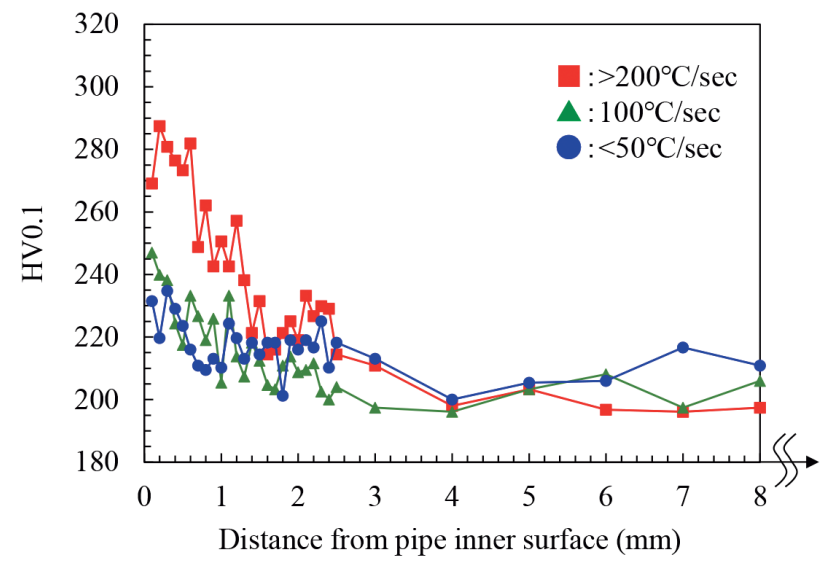

Fig. 3. Hardness distribution in thickness direction in three different cooling rate pipes. (Online version in color.)

Table 1. Four-point bend testing conditions.

\begin{tabular}{|c|c|c|c|c|}
\hline \multirow{2}{*}{$\begin{array}{c}\text { Test solution } \\
\text { (NACE TM0177) }\end{array}$} & \multirow{2}{*}{$\underset{\text { (start/final) }}{\mathrm{pH}}$} & \multicolumn{2}{|c|}{ Partial pressure (bar) } & \multirow{2}{*}{ Duration(hr) } \\
\hline & & $\mathrm{H}_{2} \mathrm{~S}$ & $\mathrm{CO}_{2}$ & \\
\hline \multirow{3}{*}{$\begin{array}{c}\text { Solution A } \\
(5.0 \mathrm{wt} \% \mathrm{NaCl}+ \\
0.5 \mathrm{wt} \% \mathrm{CH} 3 \mathrm{COOH})\end{array}$} & \multirow{3}{*}{$\begin{array}{c}2.6 \text { to } 2.8 \\
/<4.0\end{array}$} & 1 & - & \multirow{3}{*}{720} \\
\hline & & 8 & 5 & \\
\hline & & 16 & 5 & \\
\hline \multirow{5}{*}{$\begin{array}{c}\text { Solution B } \\
(5.0 \mathrm{wt} \% \mathrm{NaCl}+ \\
2.5 \mathrm{wt} \% \mathrm{CH} 3 \mathrm{COOH}+ \\
0.41 \mathrm{wt} \% \mathrm{CH} 3 \mathrm{COONa})\end{array}$} & \multirow{5}{*}{$\begin{array}{c}3.4 \text { to } 3.6 \\
/<4.0\end{array}$} & 0.07 & 0.93 & \multirow{5}{*}{720} \\
\hline & & 0.10 & 0.90 & \\
\hline & & 0.13 & 0.87 & \\
\hline & & 1.3 & 3.5 & \\
\hline & & 3.3 & 5.1 & \\
\hline $\begin{array}{c}\text { Buffered solution } \\
\text { chemistry } \\
(5.0 \mathrm{wt} \% \mathrm{NaCl}+ \\
5.0 \mathrm{wt} \% \mathrm{CH} 3 \mathrm{COOH}+ \\
0.40 \mathrm{wt} \% \mathrm{CH} 3 \mathrm{COONa})\end{array}$ & $\begin{array}{c}3.0 \text { to } 3.2 \\
/<3.5\end{array}$ & 0.15 & 0.85 & 720 \\
\hline
\end{tabular}

評価した。また，同じ切断した試験片を用いて表層下 0.25 $\mathrm{mm}$ 位置での硬さ（HV0.1）を $1 \mathrm{~mm}$ ピッチで測定し, 30 点 測定の最大值で評価した。試験後の腐食量を評価するた め, 試験前後の重量減量を測定した。試験後の腐食生成物 を採取し, XRD (X-ray Diffaction) 測定による表面腐食生成 物分析を実施した。X 線回折条件はC CuK $\alpha$ 線 $40 \mathrm{kV}-200 \mathrm{~mA}$ とした。RAMAN 分光分析による腐食生成物の相同定も実 施した。RAMAN 分光分析には532 nmの励起波長を用い, 100 倍の対物レンズを通して測定した。

\section{$2 \cdot 3$ SSC 機構評価の電気化学試験方法（分極測定）}

初期の腐食挙動に及ぼす $\mathrm{H}_{2} \mathrm{~S}$ 分圧の影響について評価す るために, NACE TM 0177 Method A ${ }^{22)}$ に基づき, 一定の引 張荷重条件下で電気化学試験を実施し, 分極曲線を測定し た。供試鋼は $200^{\circ} \mathrm{C} / \mathrm{sec}$ を超える高い冷却速度の時効後パ イプを用いた。試験片形状を Fig.6に示す。丸棒引張試験片 をパイプ内表面から $5 \mathrm{~mm}$ の位置を中心に採取し, 一定面

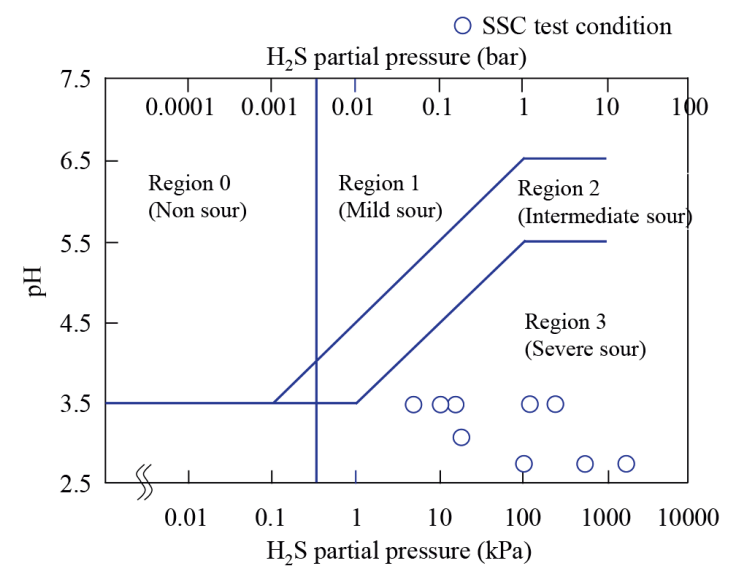

Fig. 4. SSC severity map and test conditions. (Online version in color.)

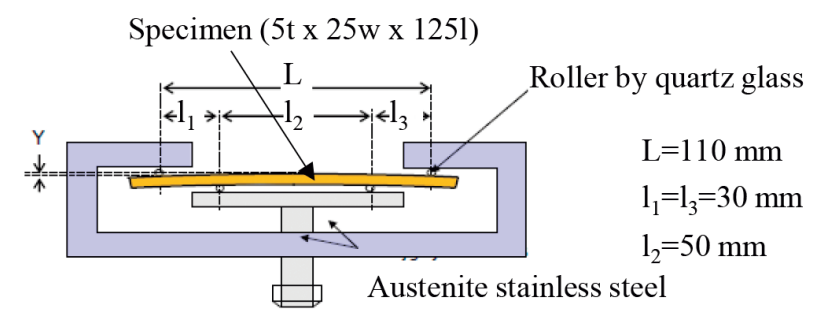

Fig. 5. Schematic illustration of four-point bend loading jig. (Online version in color.)

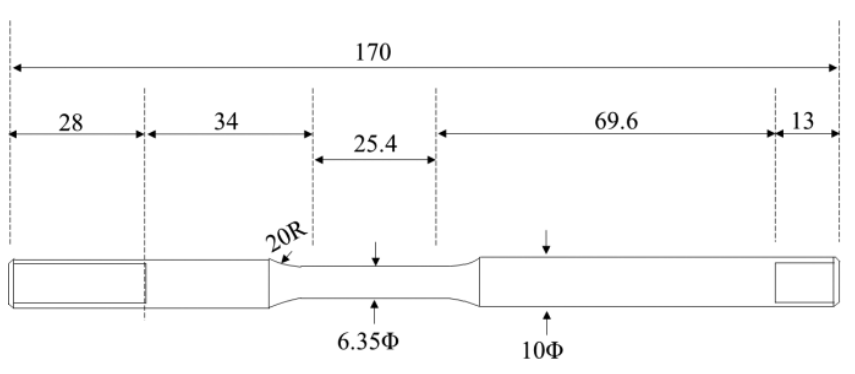

Fig. 6. Specimen shape. 
積のみが露出するように試験片表面を被覆した。試験水準 をTable2に示す。AYSの 90\%の定荷重を負荷し，0.15 bar $\mathrm{H}_{2} \mathrm{~S}$, NACE Sol.B, pH 3.1 条件打よび1 bar $\mathrm{H}_{2} \mathrm{~S}$, NACE Sol. $\mathrm{A}, \mathrm{pH} 2.7$ の条件で実施した。分極は, 試験ガス飽和後から 72 時間まで自然浸漬状態の保持時間を設け，72 時間後に, その時点における自然電位 (OCP : Open Circuit Potential) を 基準として, 掃引速度 $20 \mathrm{mV} / \mathrm{min}$.にて OCPから，+500 mV （vs.OCP）もしくはー500 mV（vs.OCP）にて分極測定した。 また, 腐食挙動の経時変化を調査するため, 0.5 時間の短時 間浸漬後に，その時点における自然電位を基準として，掃 引速度 $20 \mathrm{mV} / \mathrm{min}$.にて OCPから，+500 mV (vs.OCP) ア ノード側のみの分極測定も実施した。参照電極には飽和 $\mathrm{KClAg} / \mathrm{AgCl}$ 電極を用い，対極には白金電極を用いた。

\section{$2 \cdot 4$ SSC 機構評価の定電位 SSRT試験方法}

き裂伝播過程に打ける駆動力としての APC と HEの寄与 を明らかとするため, NACE TM0198 $8^{23)}$ に準拠した定電位 SSRT (Slow Strain Rate Testing) 試験を実施した。SSRT試験 は, 低ひずみ速度の引張により試験片に連続的な塑性変形 を加えて材料を破断させるもので, SSCを含む環境支援割 れの加速試験法という側面と, 龟裂先端でのすべりステッ プの生成速度を制御した方法として, 主に亀裂伝播過程の 機構解明手法としての側面の両面を有する試験法である。 供試鋼は $200^{\circ} \mathrm{C} / \mathrm{sec}$ を超える高い冷却速度の時効後パイプ を用いた。試験に用いたノッチ付き丸棒引張試験片形状 を Fig.7に示す。試験片はパイプ内表層 $5 \mathrm{~mm}$ 位置を中心に 採取した。試験条件は, 0.15 bar $\mathrm{H}_{2} \mathrm{~S}+0.85$ bar $\mathrm{CO}_{2}$, NACE

Table 2. Test conditions of electrochemical polarization characteristics.

\begin{tabular}{|c|c|c|c|c|}
\hline \multirow{2}{*}{$\begin{array}{c}\text { Test solution } \\
\text { (NACE TM0177) }\end{array}$} & \multirow{2}{*}{$\begin{array}{c}\mathrm{pH} \\
\text { (start/final) }\end{array}$} & \multicolumn{2}{|c|}{ Partial pressure (bar) } & \multirow{2}{*}{$\begin{array}{l}\text { Duration } \\
\quad(\mathrm{hr})\end{array}$} \\
\hline & & $\mathrm{H}_{2} \mathrm{~S}$ & $\mathrm{CO}_{2}$ & \\
\hline \multirow{2}{*}{$\begin{array}{c}\text { Solution A } \\
(5.0 \mathrm{wt} \% \mathrm{NaCl}+ \\
0.5 \mathrm{wt} \% \mathrm{CH} 3 \mathrm{COOH})\end{array}$} & \multirow{2}{*}{$\begin{array}{l}2.6 \text { to } 2.8 \\
1<4.0\end{array}$} & \multirow{2}{*}{1} & \multirow{2}{*}{-} & 72 \\
\hline & & & & 0.5 \\
\hline \multirow{2}{*}{$\begin{array}{c}\text { Solution B } \\
(5.0 \mathrm{wt} \% \mathrm{NaCl}+ \\
2.5 \mathrm{wt} \% \mathrm{CH} 3 \mathrm{COOH}+ \\
0.41 \mathrm{wt} \% \mathrm{CH} 3 \mathrm{COONa})\end{array}$} & \multirow{2}{*}{$\begin{array}{l}3.0 \text { to } 3.2 \\
\quad /<4.0\end{array}$} & \multirow{2}{*}{0.15} & \multirow{2}{*}{0.85} & 72 \\
\hline & & & & 0.5 \\
\hline
\end{tabular}

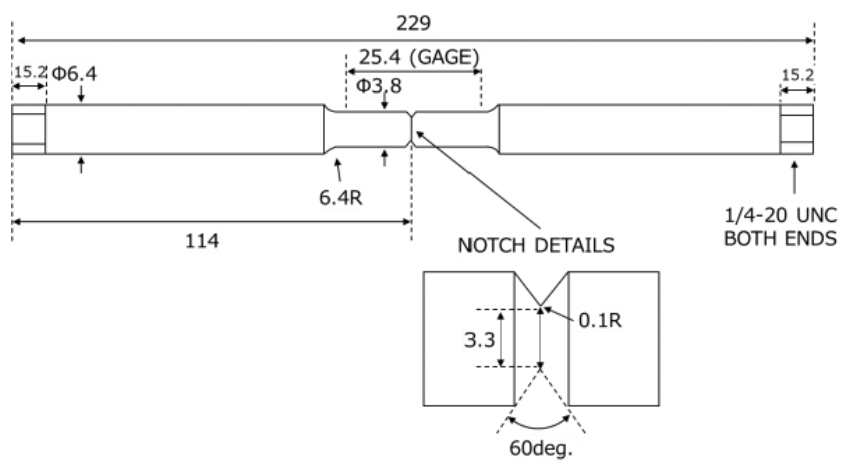

Fig. 7. Schematic of the notched round bar tensile specimen.
Sol.B（pH 3.1）の溶液環境，または大気とし，歪速度 $4 \times$ $10^{-7} / \mathrm{s}$ とした。な打, SSRT試験は，き裂伝播過程の現象そ のものは 4 点曲げSSC 試験と同じだが, 一定の歪速度が連 続的に付与されるため, 4点曲げSSC試験より厳格環境で あり，高 $\mathrm{H}_{2} \mathrm{~S}$ 環境では電位変化時の影響が明確とならない 可能性があったため, 低 $\mathrm{H}_{2} \mathrm{~S}$ 環境とした。また, 一部試験 片に対しては, 自然浸漬電位 $(-644 \mathrm{mV}$ vs. SCE) に対して, それぞれ $+50 \mathrm{mV},+100 \mathrm{mV},-50 \mathrm{mV},-100 \mathrm{mV}$ の定電 位を印加しながら試験を実施した。なお，参照電極には飽 和カロメル電極を，対極には白金電極を用いた。

SSRTによるSSC伝播特性の評価は，サワー環境中での 破断時間と大気中での破断時間の比をもとに，判定した。 例えば，早期破断した材料は，サワー環境での脆化感受性 が高いことを意味する。また，定電位条件と破断時間の関 係から，き裂進展 (伝播) 過程での支配的駆動力 (APC お よびHE）を判定可能である。

\section{$2 \cdot 5$ SSC 機構評価の歪漸増型破壊勒性試験方法 (CT 試} 験片)

き裂発生/伝播過程におけるサワー環境の影響を調査す るため, 歪漸増型破壊勒性試験を実施した。試験ガスは, $\mathrm{H}_{2} \mathrm{~S}$ 分圧に着目し, 0.15 bar $-\mathrm{H}_{2} \mathrm{~S}+0.85$ bar- $\mathrm{CO}_{2}$, Standard 条件の 1 bar- $\mathrm{H}_{2} \mathrm{~S}, 16$ bar- $\mathrm{H}_{2} \mathrm{~S}+5$ bar- $\mathrm{CO}_{2}$ の3 水準とした。 供試鋼は $50^{\circ} \mathrm{C} / \mathrm{sec}$ 未満の低い冷却速度の時効後パイプを用 いた。ASTM E1820/2に準拠したCT (Compact Tension) 試 験片形状をFig.8 に示す。試験片厚は $12.7 \mathrm{~mm}$ とした。試験 片はパイプ板厚中央から採取し，き裂進展方向は管周方向 とした。試験溶液はNACE Sol. Aを用い, pH2.7 とした。き 裂発生までの荷重速度 $\mathrm{dK} / \mathrm{dt}$ は，事前に種々の荷重速度で 試験を行い，最小の破壊勒性值を示した $0.005 \mathrm{~N} \cdot \mathrm{mm}^{-3 / 2} / \mathrm{s} て ゙$ 一定とした。試験は単一試料法とし，水素をき裂先端近傍 で定常濃度にするため, 試験片を溶液に 4 日間予備浸漬し た。き裂長さは直流電位降下 (Direct Current Potential Drop, DCPD）法を用いてモニターし, Johnson方程式（ASTM E1457-0 $7^{24)}$ ) を用いてき裂長さに変換した。試験後, 試験 片を破断し, 実際の初期き裂長さと最終き裂長さを実体顕 微鏡で測定し, ASTM E1457-07 $7^{24)}$ に従って補正した。き 裂開口変位 (Crack Mouth Opening Displacement, CMOD) を

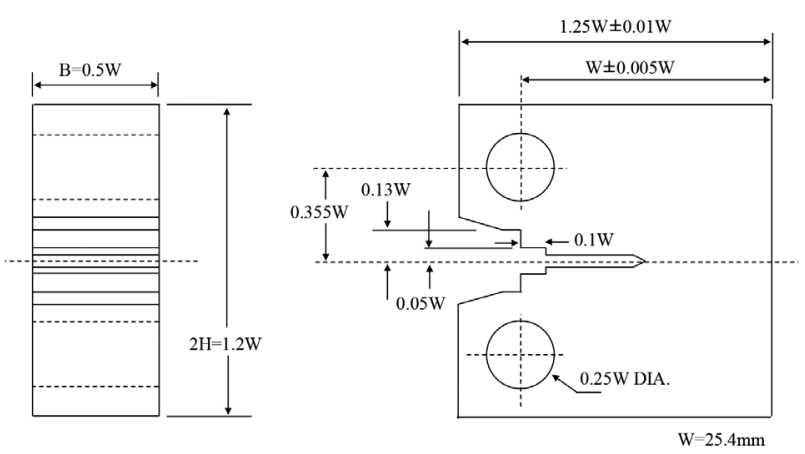

Fig. 8. Schematic of the CT specimen. 
算出し, 応力拡大係数 $\mathrm{K}$ 打よび破壊勒性值 $\mathrm{J}$ 求めた。

\section{3. 実験結果と考察}

\section{$3 \cdot 1 \quad 4$ 点曲げSSC 試験による耐 SSC 性能評価}

\section{$3 \cdot 1 \cdot 1$ 而 SSC 性能}

Fig.9に 4 点曲げ SSC 試験結果を示す。各試験片の試験後 の表層 $0.25 \mathrm{~mm}$ 位置の硬さ $\mathrm{HV} 0.1$ の最大值打よび $\mathrm{H}_{2} \mathrm{~S}$ 分圧 と割れの有無を示している。1 bar以上の $\mathrm{H}_{2} \mathrm{~S}$ 分圧の場合, 4 点曲げSSC試験で割れが発生しない表層硬度の限界は約 250 HV0.1であった。0.13 barの場合, 表層硬度の限界は約 270 HV0.1であり, 0.07 barでは, SSC発生は見られなかっ た。 $200^{\circ} \mathrm{C} / \mathrm{sec}$ を超える高い冷却速度のサンプルで主に SSC が発生し, $16 \mathrm{bar}$ の場合, 一部 $100^{\circ} \mathrm{C} / \mathrm{sec}$ のサンプルで $\mathrm{SSC}$ が発生した。 $200^{\circ} \mathrm{C} / \mathrm{sec}$ を超える高い冷却速度のサンプル は, 板厚方向 (約 $1 \mathrm{~mm}$ ) と幅方向 (約 $10 \mathrm{~mm}$ ) の広い領域 で 250 HV0.1を超える高硬度を示したことから, SSCが発 生すると厚み方向にき裂が伝播しやすいと考えられる。な お, $200^{\circ} \mathrm{C} / \mathrm{sec}$ を超える高い冷却速度のサンプルの中で, 四 角マークのサンプルは $350^{\circ} \mathrm{C}$ 未満の低温域で泠却停止して

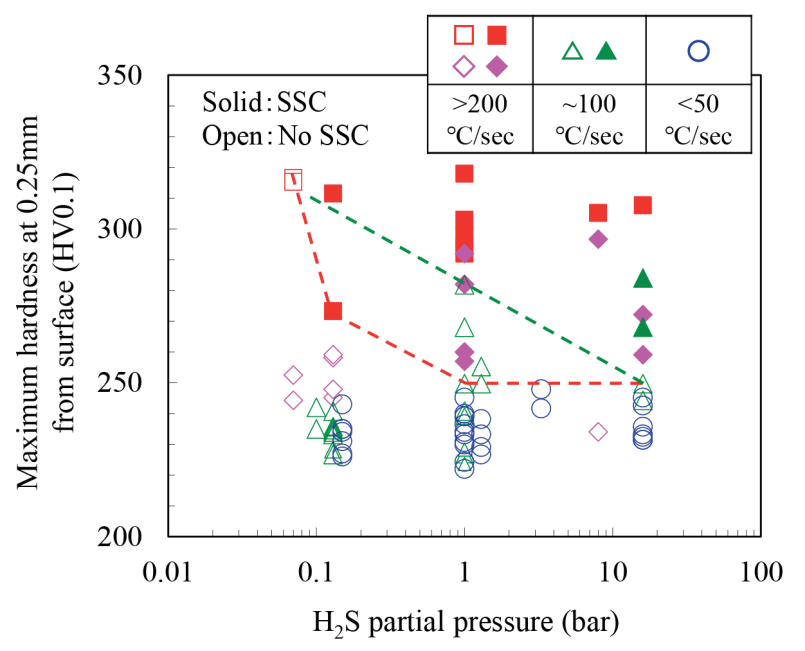

Fig. 9. Effect of $\mathrm{H}_{2} \mathrm{~S}$ partial pressure and surface hardness on SSC by four-point bend test.
おり, 菱形マークの $350^{\circ} \mathrm{C}$ 以上の冷却停止のサンプルと比 較して, 表層 $0.25 \mathrm{~mm}$ 位置の硬さHV0.1 が高くなる傾向に あり, 0.07 barの条件を除いて, SSCが発生した。

結果をまとめると，硬質のLB組織を抑制し GB 組織主 体とすることで, 表層 $0.25 \mathrm{~mm}$ 位置の硬さが $250 \mathrm{HV} 0.1$ 以 下となり, $\mathrm{H}_{2} \mathrm{~S}$ 分圧条件に拠らず，良好な耐 SSC 性能が得 られることが分かった。一方, 1 bar 以上の $\mathrm{H}_{2} \mathrm{~S}$ 分圧条件下 に扔いて, LB組織の体積分率が増加し, パイプ内面の表層 硬度が $250 \mathrm{HV} 0.1$ を超えて高くなった場合, $\mathrm{H}_{2} \mathrm{~S}$ 分圧が高 くなるほど, SSCが発生しやすくなることが明らかとなっ た。これら極表層 $0.25 \mathrm{~mm}$ 位置の硬さ HV0.1 と耐 SSC 性能 の関係は, 従来の $\mathrm{H}_{2} \mathrm{~S}$ 分圧 $1 \mathrm{bar}$ 以下の条件に打ける表層 1.5 $\mathrm{mm}$ 位置の硬さHV10 と耐 SSC 性能の関係》 と傾向として は打打むね一致した。一方，極表層 $1.5 \mathrm{~mm}$ 以内の範囲のミ クロ組織や硬さHVO.1の分布の違いにより, 而 SSC 性能が 異なっていることを今回新たに知見し, 極表層のミクロ組 織や硬さの制御が非常に重要であることがわかった。

$3 \cdot 1 \cdot 24$ 点曲げ SSC 試験後の腐食生成物評価

4 点曲げ腐食 試験後の表面写真と試験片断面写真を Fig. 10 に示す。 $0.15 \mathrm{bar} \mathrm{H}_{2} \mathrm{~S}$ 条件の鋼材表面には, $10 \mu \mathrm{m}$ 以下の 薄い腐食生成物層が堆積していた。一方, 1 bar 打よび16 bar $\mathrm{H}_{2} \mathrm{~S}$ 条件の鋼材表面には, 腐食生成物が多く堆積してお り，それぞれ100〜200 $\mu \mathrm{m}, 50 \sim 100 \mu \mathrm{m}$ の厚さの腐食生成 物層が認められた。また, 試験後の腐食減量と最大局部腐

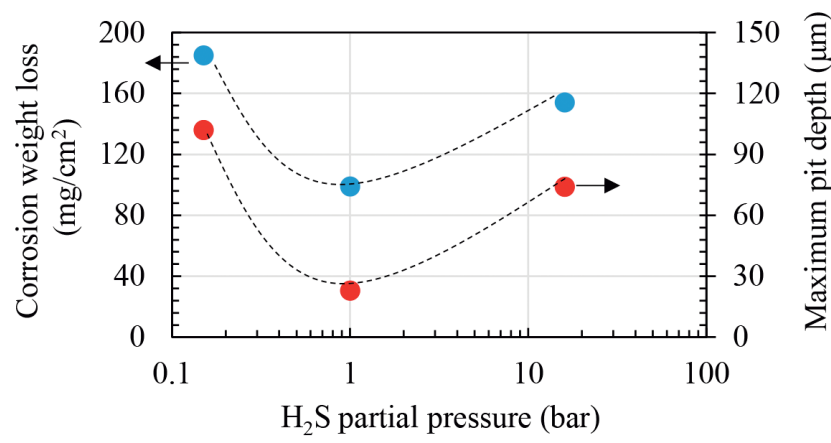

Fig. 11. Corrosion weight loss and maximum corrosion depth in each $\mathrm{H}_{2} \mathrm{~S}$ partial pressure condition.

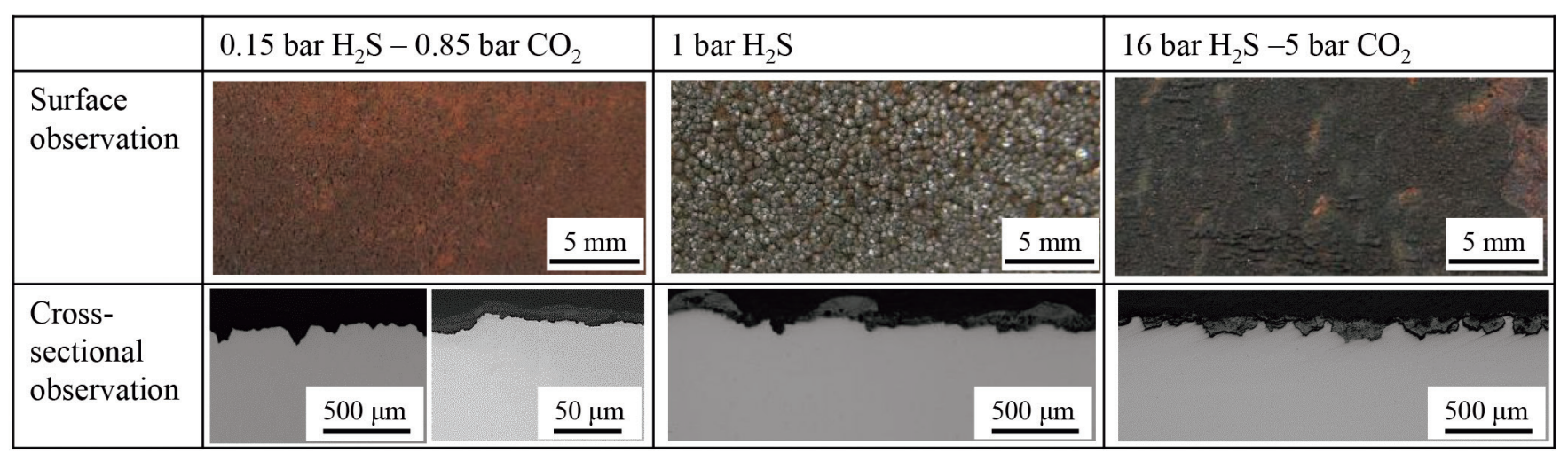

Fig. 10. Surface and cross-sectional observation results in each $\mathrm{H}_{2} \mathrm{~S}$ partial pressure condition. 
食深さに及ぼす $\mathrm{H}_{2} \mathrm{~S}$ 分圧の影響を Fig. 11 に示す。腐食減量, 局部腐食深さ共に $0.15 \mathrm{bar}$ で最も大きく, $1 \mathrm{bar}$ 条件で最も 小さい值を示した。すなわち, 全面腐食性, 局部腐食共に, 0.15 barが最も撖しく, 1 barが最も軽微であるとわかった。 続いて, 4 点曲げ腐食試験後の腐食生成物を対象とした

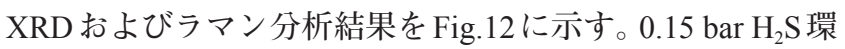
境では， $\gamma \mathrm{Fe}_{2} \mathrm{O}_{3}$ を主体とした腐食生成物であるとわかっ た。一方， 1 bar $\mathrm{H}_{2} \mathrm{~S} て ゙ は ， \mathrm{FeS}$ を主体とした組成であり，わ

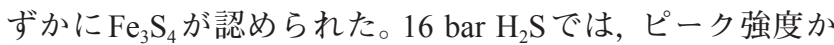
ら $\mathrm{Fe}_{3} \mathrm{~S}_{4}$ の割合がさらに増加していると認められた。一般 に, FeSを主体とした腐食生成物は腐食保護作用を示すこ とが知られている ${ }^{25)}$. 1 bar $\mathrm{H}_{2} \mathrm{~S}$ 環境において腐食生成物層
が最も厚く堆積していた事実（Fig.10）も踏まえ， 1 bar $\mathrm{H}_{2} \mathrm{~S}$ 環境での低い腐食量は，この FeSを主体とした厚い腐食生 成物層の保護作用に起因すると推定される。

\section{$3 \cdot 2$ SSC 機構評価の電気化学測定試験結果}

0.15 bar および 1 bar $\mathrm{H}_{2} \mathrm{~S}$ サワー環境への 72 時間 および 0.5 時間保持時点で得た分極測定結果を Fig. 13 と Fig. 14 に それぞれ示す。72時間時点での分極測定結果，カソード分 極曲線に関して, 両 $\mathrm{H}_{2} \mathrm{~S}$ 分圧条件において明確な差は認め られなかった。一方，アノード分極曲線の関しては，1 bar $\mathrm{H}_{2} \mathrm{~S}$ 条件において，アノード電流が抑制されていると認め られた。また, 0.5 時間と 72 時間浸漬時点でのアノード分 極曲線の比較から, 浸漬時間が長くなるほど，アノード電

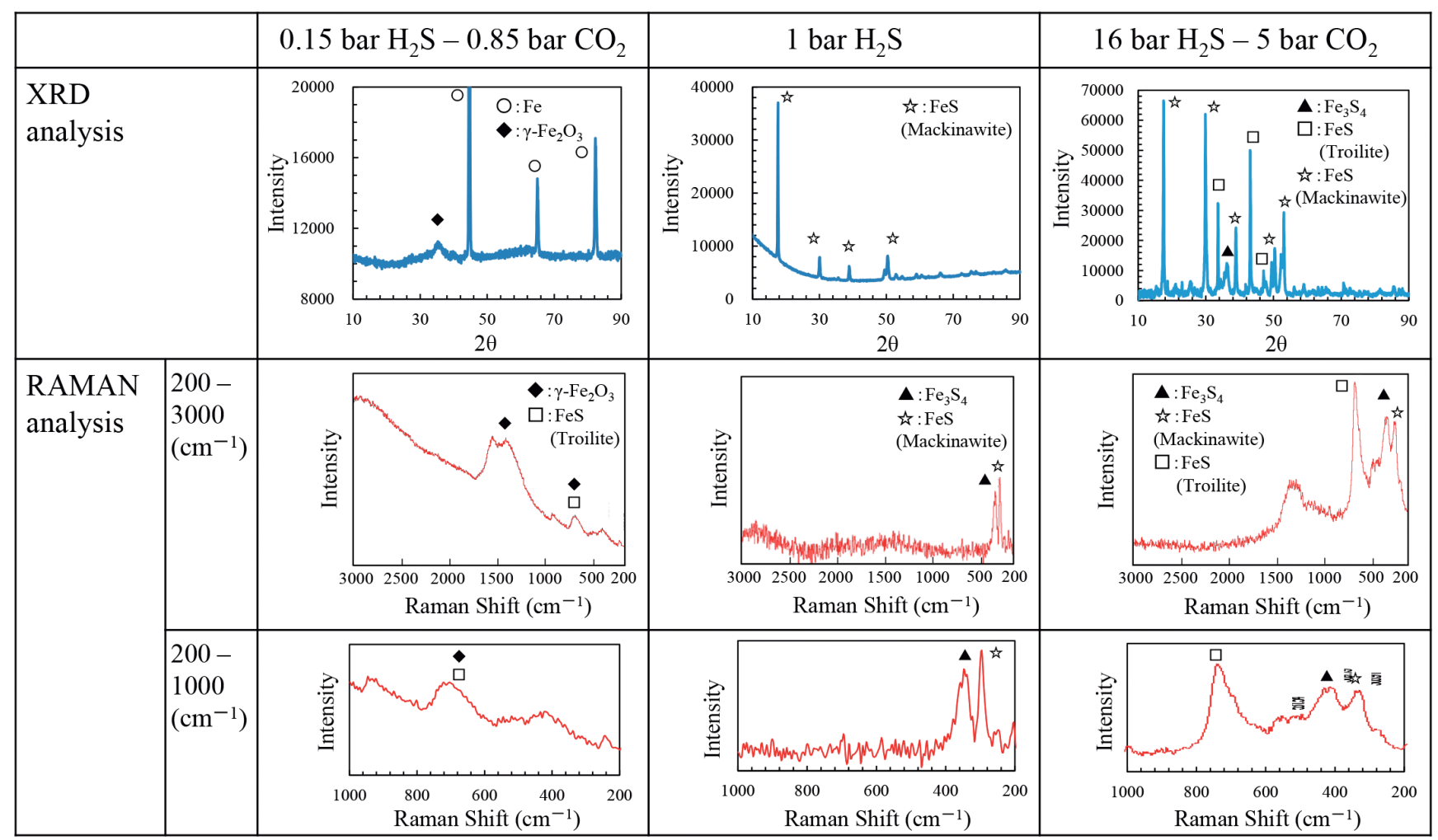

Fig. 12. XRD and RAMAN analysis results. (Online version in color.)

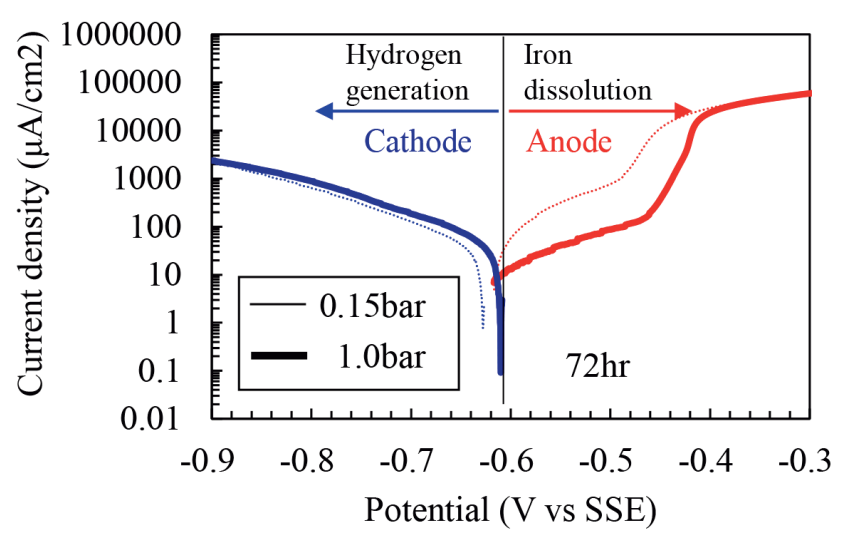

Fig. 13. Polarization property in sour environment ( 0.15 and 1.0 bar $\mathrm{H}_{2} \mathrm{~S}, 72 \mathrm{hr}$ immersion). (Online version in color.)

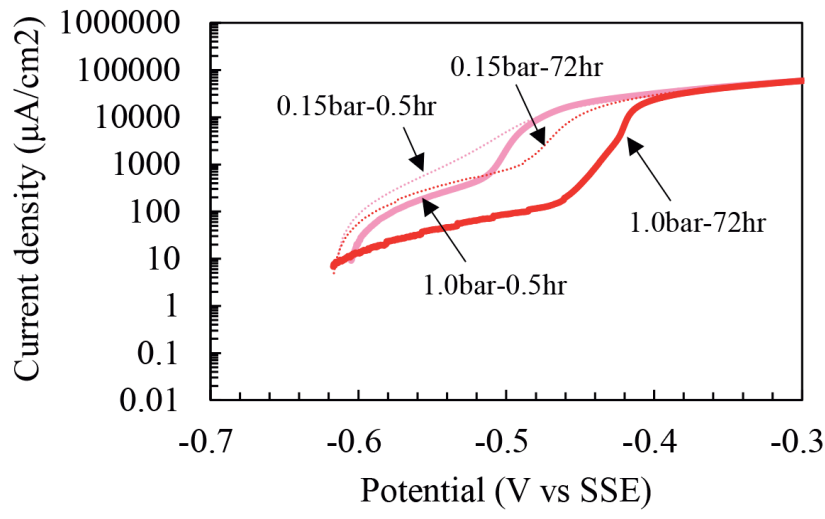

Fig. 14. Effect of immersion time on polarization property in sour environment $\left(0.15\right.$ and 1.0 bar $\mathrm{H}_{2} \mathrm{~S}, 0.5$ and $72 \mathrm{hr}$ immersion). (Online version in color.) 
流が抑制されると分かった。特にこの 72 時間長期浸漬によ るアノード抑制は, 1 barにて顕著であった。本分極測定結 果は, 前節の 4 点曲げ $\mathrm{SSC}$ 試験での腐食減量に対する $\mathrm{H}_{2} \mathrm{~S}$ 分圧の関係 (Fig.11) と矛盾なく対応する。すなわち, 1 bar 環境では, 0.15 bar環境よりも保護性の高い腐食生成物が 形成されることでアノード反応が抑制され，結果的に腐食 量が抑制されていると分かった。

\section{$3 \cdot 3 \mathrm{SSC}$ 機構評価の定電位 SSRT 試駼結果}

Fig.15に, 定電位SSRT試験における荷重の経時変化を 示す。サワー溶液環境では, 大気環境に比して, 著しい早 期破断が認められた。Fig.16に, 定電位SSRT試験における 破断時間率 (サワー/大気) と電位の関係を示す。定電位操 作をしない場合 $(0 \mathrm{mV})$, 破断時間率 $31 \%$ を示した。破断 時間率は, カソード側, アノード側両方で $\pm 50 \mathrm{mV}$ 条件に おいて極小值を示し，それ以上に大きい電位 $( \pm 100 \mathrm{mV})$ を与えると破断時間が長寿命化した。この結果は，カソー ド反応 (水素発生反応) とアノード反応 (鉄溶解反応) いず れも, SSC伝播の駆動力であり, 両反応のバランスにより, 伝播過程が制御されていることを意味する。また, 破断時 間は, $-50 \mathrm{mV}$ のカソード条件が最も短いことから, 伝播 現象に対して, カソード反応がアノード反応に比べて, よ り支配的に寄与しているとわかった。言い換えると, SSC き裂進展現象はHEを優勢とした, APC と HEの複合的な破 壊現象であるとわかった。なお， $+100 \mathrm{mV}$ 条件での破断時 間の長時間化は, 亀裂先端での鉄溶解反応促進による APC 型亀裂成長作用よりも, 水素発生反応量減少による HE型 亀裂成長の低下効果が大きく寄与したためと考えられる。 一方, $-100 \mathrm{mV}$ 条件での破断時間の長時間化は, HEが龟 裂伝播の優勢な脆化モードであることを踏まえて，カソー ド過電圧条件におけるAPCの寄与低下だけでは説明がつ かない。この長時間化の理由として, $-100 \mathrm{mV}$ の過剩な力 ソード過電圧条件下に扔いて, 鋼材への侵入水素量があま

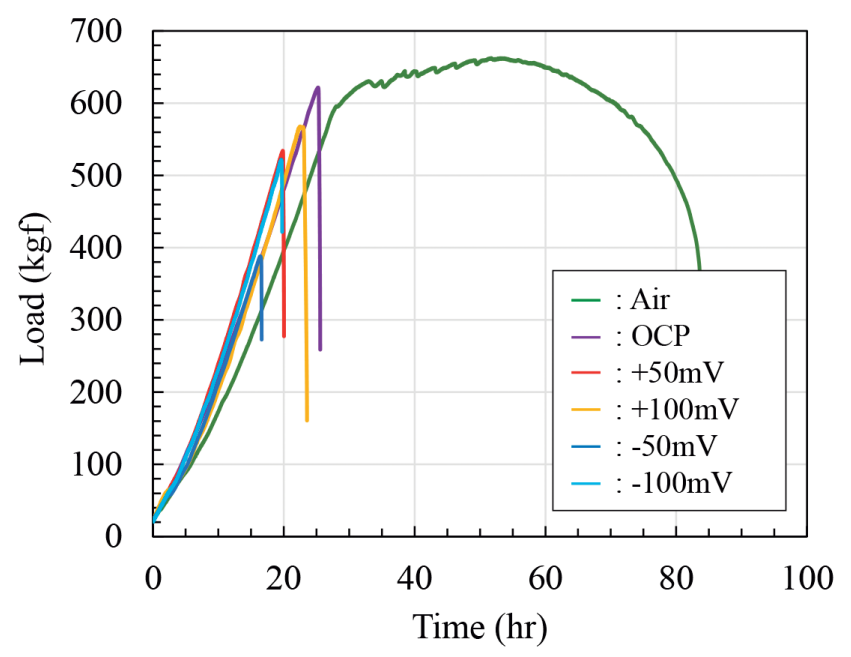

Fig. 15. Load-time curve in constant potential SSRT test.
り増加せずに, HEの駆動力が十分に増加しなかった可能 性が考元られる。 $\mathrm{H}_{2} \mathrm{~S}$ は, サワー腐食環境に打けるカソー ド反応種 ${ }^{26)}$ であるとともに, 鋼材表面で生成した水素原 子の鋼中侵入を促進する触媒とも知られている27)。すなわ ち, 一 $100 \mathrm{mV}$ の大きなカソード過電圧条件では, 水素発 生量が増加する一方, そのカソード反応により消費される $\mathrm{H}_{2} \mathrm{~S}$ 量も増加する。その結果, 鋼材表面での $\mathrm{H}_{2} \mathrm{~S}$ 濃度が低下 し, 鋼中に侵入する水素の量自体が低下して, HE亀裂伝播 が促進されなかった可能性が考えられる。

\section{$3 \cdot 4$ SSC 機構評価の歪漸増型破壊勒性試験結果}

Fig.17 に歪漸増型破壊勒性試験に打ける破壊勒性值 $\mathrm{J}$ と, き裂長さの関係を示す。き裂進展開始の破壞勒性值Jは 0.15 bar $\mathrm{H}_{2} \mathrm{~S}$ 条件と 1 bar $\mathrm{H}_{2} \mathrm{~S}$ 条件で同等であったが 16 bar $\mathrm{H}_{2} \mathrm{~S}$ 条件では大きく低い值を示した。一方, き裂が進展す るほど, J值は 16 bar条件 $<1$ bar 条件 $<0.15$ bar 条件の序列 を示し, $\mathrm{H}_{2} \mathrm{~S}$ 分圧が高いほど低い破壊勒性值であった。す なわち, 高 $\mathrm{H}_{2} \mathrm{~S}$ 分圧になることで, サワー環境中での SSC き裂伝播性が高まるとわかった。な报, 歪漸増型破壊勒性

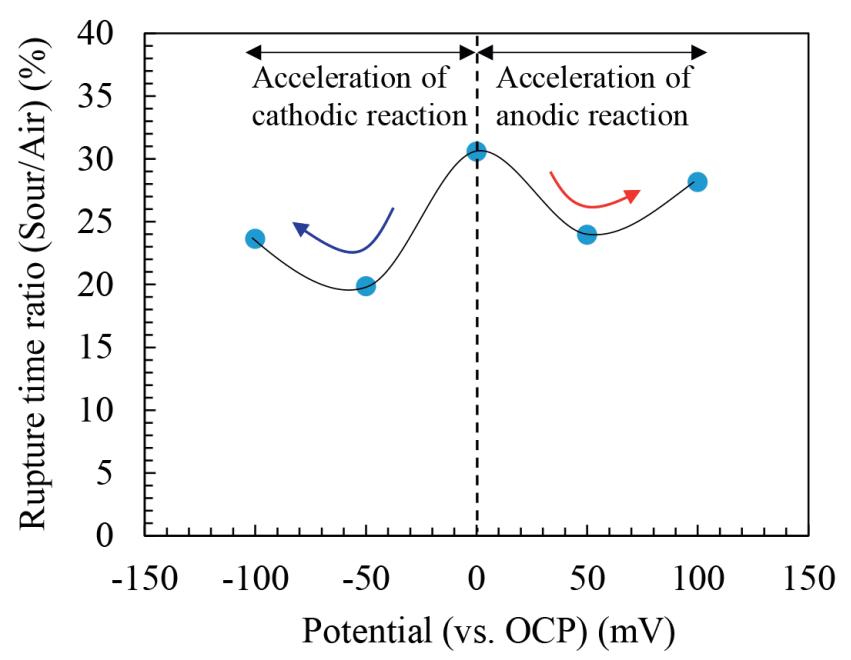

Fig. 16. Effect of potential on rupture time in constant potential SSRT test.

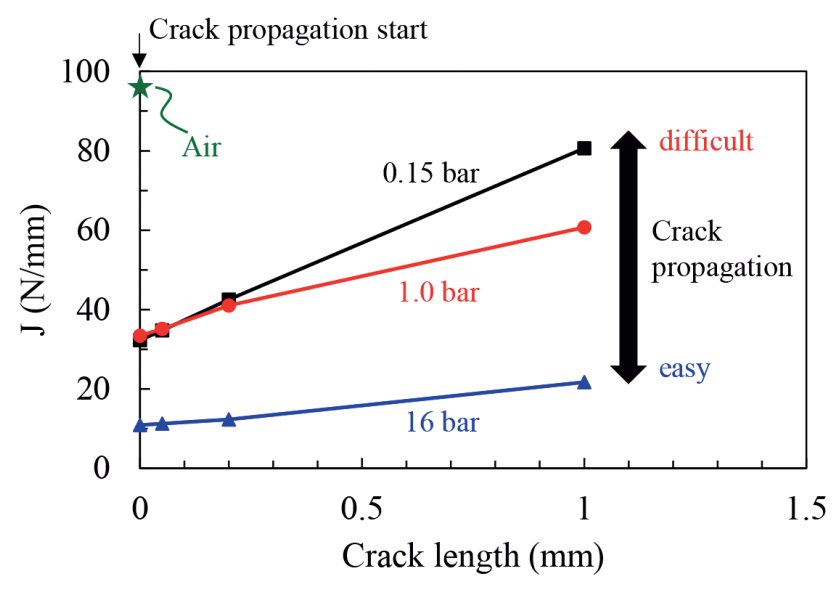

Fig. 17. Effect of $\mathrm{H}_{2} \mathrm{~S}$ partial pressure on resistance to SSC crack propagation. 
試験は，き裂発生/伝播過程のみを考慮しているのに対し， 4 点曲げSSC 試験は局部腐食過程も含む。つまり, 歪漸増 型破壊勒性試験は初期き裂の存在を前提としており，初期 き裂の形成過程（局部腐食）を考慮していない。また，亀裂 先端での応力拡大係数が常に増加し続ける環境に制御され ていることからも，SSC伝播抵抗としては実際よりも，厳 しい側の試験となっている。

\section{$3 \cdot 5$ SSC 機構まとめ}

前節までの結果を踏まえ, SSC 現象は, 局部腐食発生/成 長 (き裂起点の形成) とき裂発生/伝播の両過程から構成 されると推察される ${ }^{19,28,29)} 。 0.15$ bar $\mathrm{H}_{2} \mathrm{~S}$ 環境をべースとし た SSC 機構調査の結果，まず発生過程がアノード溶解（局 部溶解過程：APC）支配であること，その局部溶解が塑性 応力集中および材料硬質化により促進されることが明らか となっている ${ }^{30,31)}$ 。鋼材表面の硬質組織の高い腐食性のた め, 硬質組織が優先溶解する。硬質組織が溶解した箇所は 応力存在下では応力集中部となるため, 応力による転位導 入を駆動力として，優先溶解サイトとして固定化される。 このように形成された局部腐食部では，溶液環境中のアニ オン $\left(\mathrm{Cl}^{-}, \mathrm{HS}^{-}\right.$等 $)$の濃化が進行する ${ }^{30)}$ 。すなわち, 腐食 が開始すると，アニオンがアノードに向って移動（電気泳 動) する。この結果，アノード (孔食部内部) では $\mathrm{Cl}^{-}$イオ ンと $\mathrm{Fe} 2^{+}$イオンとが塩化鉄を形成し, 加水分解反応によ り, 水酸化鉄 $\mathrm{Fe}(\mathrm{OH})_{3}$ と塩酸 $\mathrm{HCl}$ 形成し, 局部腐食内の 環境を低 $\mathrm{pH}$ 化する ${ }^{32)}$ 。この局所的な低 $\mathrm{pH}$ 化は，さらなる 鉄の溶解を引き起こし, 局部腐食成長のさらなる駆動力と なる。また, $3 \cdot 3$ 節の結果から, SSCの伝播過程が, 水素脆 化（HE）の顕在化に基づくことが確認された。以上，応力 を駆動力とした局部腐食が生じ, 局部腐食の進行に伴い, さらなる応力集中と腐食環境厳格化が進み, 水素脆化が顕 在化する, これら一連の SSC推定機構を Fig.18に示す。以 下, 局部腐食発生/成長とき裂発生/伝播の各過程での SSC 機構に及ぼす $\mathrm{H}_{2} \mathrm{~S}$ 分圧の影響について，考察する。

Fig.18の Phase 1〜3で示すように, 局部腐食の進行によ る，局部腐食内での硫化水素イオン濃化，低 $\mathrm{pH}$ 化により， 鋼材への水素侵入が増加するとともに，応力集中した腐食 先端での水素集積が生じ，水素脆化き裂への遷移が起こ る。腐食先端に硬質相が存在した場合は，水素トラップ性 が高い（内部転位）ために，水素脆化き裂が容易に生じる。 き裂の進展に伴い, き裂先端とバルク環境との溶液交換も 困難となることで，き裂内の $\mathrm{pH}$ はますます低下する。さら に，応力集中も相まって, Fig.18の Phase 4で示すように, き裂先端での活性溶解および水素脆化が強調され，き裂進 展に伴い，き裂成長速度が増加，伝播する。

Fig.19に局部腐食発生/成長とき裂発生/伝播の各過程で の SSC 機構に及ぼす $\mathrm{H}_{2} \mathrm{~S}$ 分圧の影響について模式的に示 す。局部腐食発生/成長 (き裂起点の形成)について, 0.15 bar $\mathrm{H}_{2} \mathrm{~S}$ 分圧条件は保護性を有する FeS が生成されにくい
ため, 腐食部でFeSによる保護が期待できず，応力集中に より優先腐食した箇所が腐食部として固定化される。した がって, 局部腐食性が高い。一方, 1 bar $\mathrm{H}_{2} \mathrm{~S}$ 条件は, 保護 性の高い FeS が生成する環境であるため, 腐食に伴って鋼 材の耐食性が高まり, 局部腐食も形成され難い。しかしな がら，ひとたび十分に成長した局部腐食部が形成された場 合，優先な局部腐食サイトとして固定化されやすい。また， 腐食生成物が鋼材表面に形成されやすいことから，局部腐 食部内部に打いても腐食生成物が十分に存在することとな り，局部腐食内部は高い閉鎖性を有すると考えられる。そ の結果, 局部腐食部酸性環境は保持されるため, 溶解性が 一層高まる。さらに，この閉鎖性に基づき，局部腐食内部 の溶液抵抗が増大し，IRドロップによる電位の卑化が生じ 得る ${ }^{33)}$ 。この卑化は, 局部腐食部先端で水素発生をもたら し，局部腐食部での HEへの移行を助長する可能性がある。 高圧の 16 bar $\mathrm{H}_{2} \mathrm{~S}$ 分圧条件は, $\mathrm{FeS}$ を含む腐食生成物が表面 に堆積するものの，性状がもろく，保護性が 1 bar条件より も得られない。また，高 $\mathrm{H}_{2} \mathrm{~S}$ 環境であるため，腐食環境自 体が㛜格であり, 優先腐食サイト以外でも腐食速度は十分 速く, 全面腐食性が高い。

き裂発生/伝播過程について，3・4節で述べたように， 局部腐食を考慮しない場合においては，高 $\mathrm{H}_{2} \mathrm{~S}$ 分圧ほどき 裂発生・伝播は促進される。これは, $\mathrm{H}_{2} \mathrm{~S}$ による鋼材への 水素侵入促進による HEの促進に基づくと解釈できる。局 部腐食を考慮すると, 16 bar $\mathrm{H}_{2} \mathrm{~S}$ 条件では局部腐食の形状 が半円状であるため, 応力集中が生じづらく, き裂に遷 移しづらくなるため, 特に GB主体組織の 4PB SSC 試験で は 1 bar $\mathrm{H}_{2} \mathrm{~S}$ 条件と同等の SSC感受性 (SSC硬さ閾值が同 じ）となったと考えられる。一方, LB + GB混合組織の 250 HV0.1を超える領域では, HE感受性が高く, Fig.19に示す ように, 16 bar $\mathrm{H}_{2} \mathrm{~S}$ 環境の方が，き裂への遷移が容易となっ たものと推察される。また，上述のとおり，1 bar環境では， IRドロップに基づき，局部腐食内部での水素発生性が高 いと推定される。すなわち, 0.15 barに対して, 1 barが高い $\mathrm{SSC}$ 感受性を示す理由としては, 環境中の高濃度 $\mathrm{H}_{2} \mathrm{~S}$ によ る鋼材への水素侵入量の増加のみならず, 局部腐食部での 水素発生量自体が増大したことによる, HEき裂への遷移 の容易さも寄与している可能性がある。

なお，今回のSSC機構に関する実験は極表層から離れ た位置から採取した試験片のため, Fig.3に示すように 250 HV0.1 未満の軟質 GB 主体組織をべースとした議論であり, 硬質の GB + LB 混合組織や LB主体組織では, 初期APCに 及ぼす影響やSSC き裂発生・伝播に寄与する HEに及ぼす 影響がより顕著となることが，4PB SSC 試験やその他試験 結果から予想される。これら詳細なミクロ組織の影響につ いては，今後さらに追加検証予定である。 


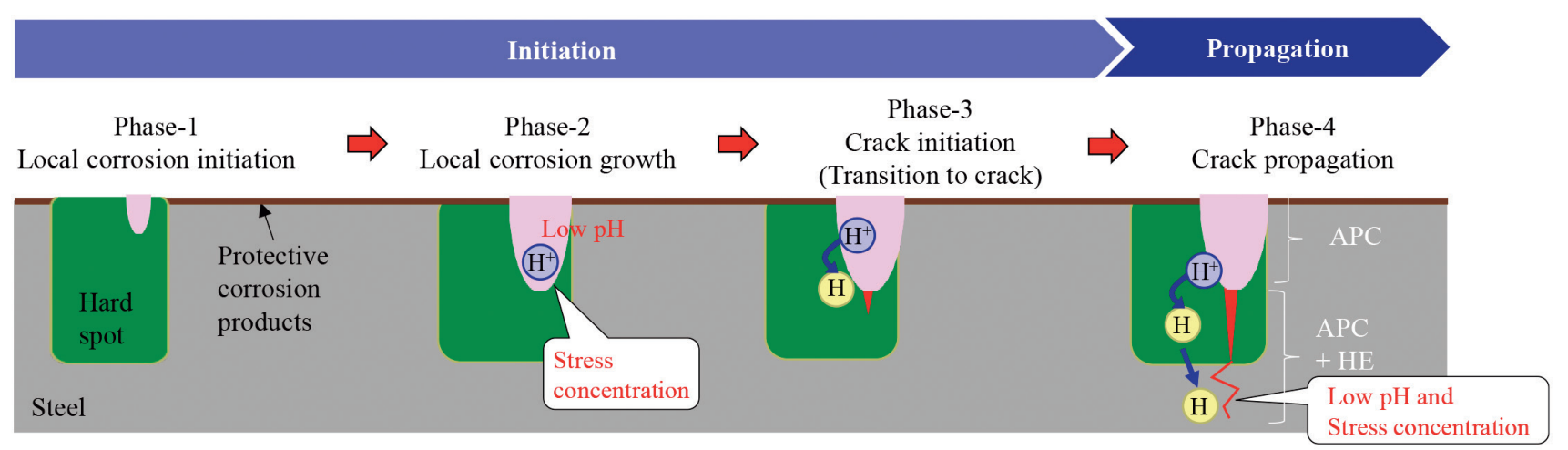

Fig. 18. Schematic diagram of estimated SSC mechanism.

\begin{tabular}{|c|c|c|c|c|}
\hline & & 0.15 bar $\mathrm{H}_{2} \mathrm{~S}$ & $1 \mathrm{bar} \mathrm{H}_{2} \mathrm{~S}$ & 16 bar $\mathrm{H}_{2} \mathrm{~S}$ \\
\hline \multirow[t]{2}{*}{ 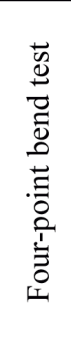 } & $\begin{array}{l}\text { Local } \\
\text { corrosion } \\
\text { initiation/ } \\
\text { growth }\end{array}$ & $\begin{array}{l}\text { Corrosion rate is high } \\
\text { due to low protection. }\end{array}$ & $\begin{array}{l}\text { Corrosion rate is low } \\
\text { due to high protection. } \\
\text { lo difficicult exchange. } \\
\text { lifid is low due }\end{array}$ & $\begin{array}{l}\text { Corrosion rate is high even } \\
\text { at sites other than priority } \\
\text { corrosion sites due to severe } \\
\text { environment }\end{array}$ \\
\hline & $\begin{array}{l}\text { Local corrosion } \\
\text { resistance }\end{array}$ & Low & High & Middle \\
\hline \multirow{4}{*}{ 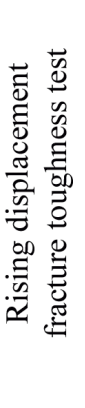 } & $\begin{array}{l}\text { Crack } \\
\text { initiation }\end{array}$ & & & \\
\hline & $\begin{array}{l}\text { Crack initiation } \\
\text { resistance }\end{array}$ & High & Middle & Low \\
\hline & $\begin{array}{l}\text { Crack } \\
\text { propagation }\end{array}$ & & & \\
\hline & $\begin{array}{l}\text { Crack propagation } \\
\text { resistance }\end{array}$ & High & Middle & Low \\
\hline
\end{tabular}

Fig. 19. Effect of $\mathrm{H}_{2} \mathrm{~S}$ partial pressure condition on local corrosion process and SSC crack initiation / propagation process.

\section{4. 結言}

サワー環境において, 低合金鋼ラインパイプの硫化物応 力腐食割れ (SSC) 挙動に及ぼす極表層硬さ分布および $\mathrm{H}_{2} \mathrm{~S}$ 分圧の影響について 4PB SSC 試験で調査した結果, ならび にSSC 機構解明を試みた結果，以下の結論が得られた。

（1）４点曲げSSC試験において, SSC発生の極表層硬さ限 界值は, 0.07 barから 1 barまでは $\mathrm{H}_{2} \mathrm{~S}$ 分圧の増加とと もに減少し, 1 bar以上に拈いては, 250 HV0.1で一定 であった。

（2）表層冷却速度を低減し, LB 組織を抑制し, GB主体組 織とすることで安定的に低硬度 $250 \mathrm{HV} 0.1$ 以下を確保 することができ, 1 bar以上の $\mathrm{H}_{2} \mathrm{~S}$ 分圧においても耐 $\mathrm{SSC}$ 性が向上した。

（3）250 HV0.1を超えて GB＋LB混合組織となった場合, 高 $\mathrm{H}_{2} \mathrm{~S}$ 分压ほど SSC 感受性は高まった。

（4）腐食過程への $\mathrm{H}_{2} \mathrm{~S}$ 分圧の影響について, 腐食減量, 局
部腐食深さ共に 0.15 barで最も大きく, 1 bar条件では 腐食が抑制されていた。1 bar条件では腐食生成物とし てタイトな FeSが材料表面に生じており, この腐食生 成物による鉄溶解反応の抑制が，電気化学的に確認さ れた。 $\mathrm{H}_{2} \mathrm{~S}$ は保護性腐食生成物 FeS の形成に影響し, 結 果としてサワー腐食性の影響因子となっていると示唆 された。

(5) SSC 伝播過程への $\mathrm{H}_{2} \mathrm{~S}$ 分圧の影響について, 高 $\mathrm{H}_{2} \mathrm{~S}$ 分圧 になることでサワー環境中での龟裂成長性伝播性が高 まるとわかった。本理由としては, 0.15 bar $\mathrm{H}_{2} \mathrm{~S}$ での伝 播駆動力の一つが水素脆化であることを踏まえ, $\mathrm{H}_{2} \mathrm{~S}$ による水素脆化の促進と推定される。

（6）SSCの伝播はカソード反応（水素発生反応）とアノー ド反応 (鉄溶解反応) いずれもが駆動力であり, 両反 応のバランスにより, コントロールされているが, 特 に水素発生反応 (水素脆化現象) が支配的に寄与して いた。 
（7）歪漸増型破壊勒性試験において, $\mathrm{H}_{2} \mathrm{~S}$ 分圧が 0.15 bar $(+$ 0.85 bar- $\left.-\mathrm{CO}_{2}\right)$ から, 1 bar, 16 barに変化した場合, き裂 発生・伝播ともに促進される傾向が見られた。

\section{文献}

1 ) Bull. Iron Steel Inst. Jpn., 9(2004), 2 (in Japanese).

2 ) N.Ishikawa, T.Shinmiya, S.Endo, T.Wada and J.Kondo: Proc. 22nd Int. Conf. on Offshore Mechanics and Arctic Engineering, ASME, New York, (2003), OMAE2003-37065.

3 ) T.Fukunaga: Bull. Jpn. Inst. Met., 16(1977), 789 (in Japanese).

4 ) A.Ikeda: Tetsu-to-Hagané, 70(1984), 792 (in Japanese).

5 ) H.Asahi: Zairyo-to-Kankyo, 49(2000), 201 (in Japanese).

6 ) L.W.Vollmer: Corrosion, 8(1952), 236.

7 ) A.A.Omar: Corrosion/81, NACE, Houston, TX, (1981), 186.

8 ) S.Endo, M.Nagae, Y.Kobayashi and K.Ume: ISIJ Int., 34(1994), 217.

9 ) R.J.Pargeter: Corrosion/2000, NACE, Houston, TX, (2000), 143.

10) K.Horikawa: Tetsu-to-Hagané, 54(1968), 610 (in Japanese).

11) M.Kimura: Corrosion/85, NACE, Houston, TX, (1985), 237.

12) M.Zhao, M.Liu, A.Atrens, Y.Shan and K.Yang: Mater. Sci. Eng. A, 478(2008), 43

13) T.Omura, K.Kobayashi, A.Souma, T.Ohe.H.Amaya and M.Ueda: Corrosion/2013, NACE, Houston, TX, (2013), 2308.

14) NACE MR0175/ISO 15156-1: 2001, Materials for Use in $\mathrm{H}_{2} \mathrm{~S}-$ Containing Environments in Oil and Gas Production.

15) D.Fairchild, B.Newbury, T.Anderson and N.Thirumalai: Proc. 38th Int. Conf. on Ocean, Offshore and Arctic Engineering, ASME, New York, (2019), OMAE2019-96593.

16) J.Shimamura, D.Izumi, S.Igi, N.Ishikawa, S.Ueoka, K.Ihara and J. Konod: Int. J. Offshore Polar Eng., 30(2020), 2.

17) T.Anderson, D.Fairchild, B.Newbury, K.Ihara and J.Kondo: Proc. 30th Int. Offshore and Polar Engineering Conf., ISOPE, California, (2020), 2020-TPC-0735.

18) T.Omura and K.Kobayashi: Zairyo-to-Kankyo, 60(2011), 190 (in Japanese).

19) Y.Yamane, K.Motoda, H.Kurahashi and Y.Nakai: Kawasaki Steel Giho, 17(1985), 178(in Japanese).

20) M.Maki: Materia Jpn., 46(2007), 321 (in Japanese).

21) NACE TM0316: 2016, Four-Point Bend Testing of Materials for Oil and Gas Applications.

22) NACE TM0177: 2016, Laboratory Testing of Metals for Resistance to Sulfide Stress Cracking and Stress Corrosion Cracking in $\mathrm{H}_{2} \mathrm{~S}$ Environments.

23) NACE TM0198: 2016, Slow Strain Rate Test Method for Screening Corrosion-Resistant Alloys (CRAs) for Stress Corrosion Cracking in Sour Oilfield Service.

24) ASTM E1457-07: 2007, Standard Test Method of Measurement of Creep Crack Growth Rates in Metals, Annual Book of ASTM Standards.

25) W.Sun, S.Nesic and S.Papavinasam: Corrosion, 64(2008), 586.

26) Y.Zheng, J.Ning, B.Brown and S.Nešić: Corrosion, 71(2015), 316.

27) H.G.Cole: Corrosion, 1(1963), 46.

28) E.Ramírez, J.G.Gonzáles-Rodriguez, A.Torres-Islas, S.Serna, B. Campillo, G.Dominguez-Patińo and J.A.Juárez-Islas: Corros. Sci., 50(2008), 3534.

29) V.Smanio, M.Fregonese, J.Kittel, T.Cassagne, F.Ropital and B. Normand: Corros. Sci., 53(2011), 3942.

30) I.Samusawa, D.Izumi and J.Shimamura: Mater. Corros., (2021), In Press. https://doi.org/10.1002/maco.202012174

31) N.Ohtani: Tetsu-to-Hagané, 60(1974), 121 (in Japanese).

32) R.T.Foley: Corros. Eng., 20(1971), 227.

33) G.F.Kennell, R.W.Evitts and K.L.Heppner: Corros. Sci., 50(2008), 1716 